\title{
Analisis Kompetensi Kepemimpinan dan Budaya Organisasi Terhadap Kepuasan Pelanggan Melalui Perilaku Responsif (Studi pada PT Garuda Indonesia Kantor Cabang Surabaya)
}

\author{
Yunia Insanatul Karimah \\ Universitas Nahdlatul Ulama Surabaya \\ email: nia.ahmad@unusa.ac.id
}

\begin{abstract}
The purpose of this research is to find out the influence of leadership competency and organization culture to customer satisfaction either directly or indirectly through responsive behavior employees. This research has three variables namely independent variables (leadership competency and organizational culture), mediating variable (responsive behavior) and dependent variable (customer satisfaction). The population in this research are frontliners and customer of PT Garuda Indonesia Surabaya Branch Office. The technique of data collection is the census method. Data are gathered by questionnaires given to 42 frontliners and customers of PT Garuda Indonesia Surabaya Branch Office. This research used quantitative approach with multiple regression analysis. The result shows that leadership competency, organizational culture and frontliner responsive behavior have significantly influence to customer satisfaction. Responsive behavior does not mediate the influence of leadership competency and organizational culture to customer satisfaction.
\end{abstract}

Keywords: Leadership competency, organizational culture, responsive behavior, customer satisfaction

\section{PENDAHULUAN}

Perkembangan industri jasa maskapai penerbangan yang sangat pesat menyebabkan persaingan bisnis jasa penerbangan menjadi sangat tajam, baik di pasar domestik (nasional) maupun di pasar internasional (global). Untuk memenangkan persaingan, perusahaan harus mampu memberikan kepuasan kepada para pelanggannya, yaitu dengan menghasilkan kualitas pelayanan yang sesuai dengan harapan pelanggan. Dalam rangka untuk menyediakan nilai kepada pelanggan, strategi pelayanan harus mempertimbangkan manajemen dalam perusahaan pada berbagai perilaku di organisasi (Asree et al., 2010).
Adanya persaingan yang ketat dalam industri jasa penerbangan maka diperlukan sumber daya manusia yang berkualitas sebagai keunggulan kompetitif. Sumber daya manusia sebagai salah satu faktor internal yang memegang suatu organisasi dalam mencapai tujuan sehingga perlu diarahkan melalui manajemen sumber daya manusia yang efektif dan efisien. Karyawan dalam organisasi diharapkan dapat menghasilkan kinerja yang tinggi, responsif terhadap pelanggan, berorientasi pada proses, terlibat dalam kepemimpinan dan bertanggung jawab untuk menciptakan knowledge yang dapat memberikan nilai tambah bagi organisasi serta mencapai kesuksesan bisnis (Moulton et al., 2006). 
Program pengembangan kepemimpinan meliputi identifikasi kompetensi dan penciptaan model kompetensi. Sebuah kompetensi adalah sebuah keterampilan tertentu, pengetahuan, atau karakteristik yang diperlukan untuk melakukan peran secara efektif dan untuk membantu bisnis memenuhi tujuan strategisnya. Kompetensi model digunakan untuk membangun kualifikasi kepemimpinan dan meningkatkan efektivitas dalam kaitannya dengan tantangan bisnis masa depan. Kategori utama kompetensi mencakup kepemimpinan, pemikiran analitis, komunikasi, pembuatan keputusan, membangun hubungan, perencanaan strategik atau kecerdasan emosional (Emiliani, 2003).

Organisasi perlu memperbarui strategi agar dapat memenangkan tantangan bisnis. Pemimpin memainkan peran penting dalam menanggapi perubahan sumber daya, teknologi, metode pemasaran dan sistem distribusi serta mengarahkan keberhasilan organisasi. Saat ini pangsa pasar, kepuasan pelanggan, kepuasan karyawan, dan kinerja keuangan menempati prioritas utama dalam rencana strategis organisasi. Alignment antara budaya organisasi dengan rencana strategis penting untuk mencapai sasaran dan tujuan organisasi. Perusahaan dapat disebut sebagai organisasi yang memiliki aktivitas untuk memenuhi kebutuhan anggota atau karyawannya. Perilaku karyawan perusahaan mengikuti peraturan, job description, struktur organisasi dan identitas spesifik berdasarkan visi dan misi. Perusahaan didasarkan pada budaya organisasi yang dibangun oleh anggota organisasi serta menciptakan nilai. Budaya organisasi dapat disebut sebagai sumber keunggulan kompetitif bagi perusahaan untuk membedakan dari perusahaan lain (Darwis dan Djajadiningrat, 2010). Untuk menjadi pemimpin sukses salah satunya harus dapat secara akurat menilai budaya organisasi dan membantu karyawan dalam memahaminya juga. Pengetahuan tentang budaya organisasi dapat menjadi sarana yang penting untuk memahami keyakinan dan perilaku individu dalam suatu organisasi. Keberhasilan atau kegagalan budaya dapat ditentukan oleh pemimpin dan oleh orang-orang yang dipilih oleh pemimpin untuk bekerja dalam sistem. Oleh karena itu, penting bahwa pemimpin memahami dan mengenali kompleksitas dan kepentingan budaya (Mullins, 2007).

Dalam lingkungan kompetitif yang berubah, ada kebutuhan untuk mengembangkan organisasi dan fasilitas secara signifikan yang lebih fleksibel dan responsif dari yang sudah ada. Perusahaan yang peka memerlukan kemampuan untuk bertahan hidup dan berkembang di lingkungan yang kompetitif dari perubahan secara terus-menerus dan tak terduga dengan bereaksi cepat dan efektif terhadap perubahan pasar, yang dipicu oleh produk dan jasa dengan customer-designed. Kemampuan yang mengharuskan organisasi untuk menanggapi dengan lebih baik terhadap perubahan-perubahan yang terjadi di lingkungan bisnis, pada dasarnya dibagi menjadi empat kategori utama yaitu responsif, kompetensi, fleksibilitas dan kecepatan. Responsif adalah kemampuan perusahaan untuk mengumpulkan informasi dari lingkungan komersial, mengidentifikasi perubahan dan merespon dengan cepat, dan menanganinya secara reaktif atau proaktif (Büyüközkan, 2004).

Agar menjadi responsif, manajer membutuhkan informasi mengenai situasi yang mereka 
hadapi serta proyeksi tentang masa depan. Responsif termasuk bereaksi terhadap atau bahkan mengantisipasi apa yang diinginkan pelanggan. Meningkatkan fleksibilitas untuk merespon perkembangan tak terduga adalah prioritas utama. Kecepatan, fleksibilitas, dan responsif dalam organisasi saat ini adalah lebih penting daripada perencanaan strategis untuk banyak manajer. Apabila perusahaan tidak mau belajar untuk responsif, maka kelangsungan organisasi dalam jangka panjang akan diragukan (Ellinger dan Rogers, 1995).

Kepuasan pelanggan memberikan pengaruh yang penting bagi perkembangan sebuah organisasi perusahaan atau bisnis. Karena itu seorang pemimpin dari suatu organisasi bisnis sangat penting untuk dapat menunjukkan ketulusan dan kepeduliannya dalam memberikan layanan prima kepada pembeli atau pelanggan. Kepemimpinan yang professional memiliki orientasi pada kepuasan pelanggan. Karakteristik umum yang biasanya dimiliki seorang pemimpin yang menginginkan terjadinya kepuasan pelanggan di perusahaan adalah mempunyai customer satisfaction vision (Irawan, 2002).

Mencapai kepuasan pelanggan saat ini merupakan tujuan utama suatu bisnis agar dapat bertahan. Industri menganggap bahwa pemahaman terhadap perilaku pelanggan setelah pembelian awal dapat memperat hubungan organisasi dengan pelanggan lebih lama. Kepuasan pelanggan pengaruhnya pada pembelian ulang dan rekomendasi dari mulut ke mulut (word of mouth). Pengalaman menunjukkan bahwa hanya perusahaan yang berorientasi pada pelanggan dapat mencapai tujuannya yaitu mempertahankan dan memuaskan pelanggan saat ini dan pelanggan masa lalu. Perusahaan-perusahaan ini berfokus pada kebutuhan dan keinginan spesifik sasaran pelanggan dan kemudian bekerja keras untuk memaksimalkan kepuasan dengan produk atau jasa yang ditawarkan (Pizam dan Ellis, 1999).

Karakteristik dari kompetensi pemimpin serta pemahaman budaya organisasi dapat memunculkan perilaku responsif pada karyawan terhadap kebutuhan pelanggan dalam hal kualitas, kecepatan, dan fleksibilitas. Perilaku responsif dalam organisasi dapat menjadi keunggulan kompetitif dalam hal kinerja bisnis, kepuasan pelanggan, inovasi dan kinerja keuangan (Stalk and Hout: 1990).

Penelitian ini dilakukan pada karyawan frontliner dan pelanggan PT Garuda Indonesia kantor cabang Surabaya. PT Garuda Indonesia merupakan perusahaan yang bergerak dalam bidang jasa penerbangan sehingga pelayanan dan kepuasan pelanggan menjadi prioritas utama. Garuda Indonesia telah menjadi ikon maskapai penerbangan dengan pelayanan terbaik di Indonesia. Karyawan frontliner mempunyai peranan penting dalam proses pemberian pelayanan jasa secara langsung berinteraksi dengan pelanggan. Perusahaan selalu mengharapkan setiap karyawan bekerja dengan profesional dan mau memperhatikan keinginan pelanggan. Setiap karyawan frontliner merupakan sumber daya penentu dalam keberhasilan suatu perusahaan serta berperan penting dalam menciptakan kepuasan pelanggan.

Berdasarkan uraian latar belakang masalah, maka permasalahan yang dapat dirumuskan dalam penelitian ini adalah:

1. Apakah kompetensi kepemimpinan mempunyai pengaruh signifikan terhadap ke- 
puasan pelanggan di PT Garuda Indonesia Kantor Cabang Surabaya?

2. Apakah kompetensi kepemimpinan mempunyai pengaruh signifikan terhadap kepuasan pelanggan melalui perilaku responsif karyawan frontliner di PT Garuda Indonesia Kantor Cabang Surabaya?

3. Apakah budaya organisasi mempunyai pengaruh signifikan terhadap kepuasan pelanggan di PT Garuda Indonesia Kantor Cabang Surabaya?

4. Apakah budaya organisasi mempunyai pengaruh signifikan terhadap kepuasan pelanggan melalui perilaku responsif karyawan frontliner di PT Garuda Indonesia Kantor Cabang Surabaya?

\section{TINJAUAN TEORETIS DAN HIPOTESIS}

\section{Kompetensi Kepemimpinan}

Hutapea dan Toha (2008:53) mendefinisikan kompetensi sebagai karakteristik yang melekat dalam diri seseorang dimana seseorang dapat menjadi manusia yang kompeten dalam melakukan pekerjaannya dengan baik sesuai dengan kemampuan mereka yang konsisten. Ada tiga jenis kompetensi yaitu kompetensi teknis yang lebih menekankan pada pencapaian efektivitas kerja, kompetensi perilaku (konsep diri, ciri diri dan motif individu) yang lebih menekankan pada perilaku produktif yang harus dimiliki, serta kompetensi pengetahuan dan keterampilan individu yang lebih ditujukan kepada pelatihan dan pendidikan.

Menurut Wibowo (2008:86), kompetensi adalah suatu kemampuan untuk melaksanakan atau melakukan suatu pekerjaan yang dilandasi dengan keterampilan dan pengetahuan serta didukung oleh sikap kerja yang dituntut oleh pekerjaan tersebut. Kompetensi menunjukkan keterampilan atau pengetahuan yang dicirikan oleh profesionalisme dalam suatu bidang tertentu sebagai sesuatu yang terpenting dan sebagai unggulan bidang tertentu.

Para peneliti mendefinisikan kepemimpinan berdasarkan persepsi individu dan aspek dari fenomena yang paling menarik bagi mereka. Kepemimpinan telah didefinisikan dalam hal sifat-sifat, perilaku, pengaruh, pola interaksi, peran hubungan, dan pekerjaan posisi administratif. Kepemimpinan dijelaskan dalam berbagai cara dimana sebagian besar mengasumsikan dengan melibatkan proses pengaruh yang berkaitan dengan kinerja tugas (Yukl:2006).

Menurut Newstrom (2011:171), kepemimpinan adalah proses mempengaruhi dan mendukung orang lain untuk bekerja dengan antusias dalam mencapai tujuan. Kepemimpinan merupakan faktor penting yang membantu individu atau kelompok dalam mengidentifikasi tujuan, memotivasi dan membantu dalam mencapai tujuan. Tiga unsur penting dalam definisi kepemimpinan adalah pengaruh/ dukungan, usaha sukarela, dan pencapaian tujuan.

Robbins (2001:314) mendefinisikan kepemimpinan sebagai kemampuan untuk mempengaruhi suatu kelompok dalam mencapai tujuan. Organisasi membutuhkan kepemimpinan yang kuat untuk menginspirasi anggota organisasi dalam mencapai visi serta efektifitas yang optimum.

Kepemimpinan selalu berbasis manusia dan proses yaitu cara untuk memanusiakan pekerja agar menemukan talenta terbaiknya yang kelak akan melahirkan pemimpin-pemimpin baru. Menurut Agung (2007:117) kompetensi kepemimpinan mempunyai tiga indikator yaitu nilai-nilai perusahaan, kerjasama tim dan keteladanan, serta dilandasi dengan kompetensi 
teknikal (dengan indikator standar baku) dan kompetensi personal (dengan indikator komunikasi) guna mencapai kompetensi bisnis serta mengoptimalkan kinerja.

Kemampuan untuk mengidentifikasi ketrampilan dan kompetensi diperlukan oleh pemimpin industri di masa yang akan datang penting untuk perusahaan yang berharap untuk tetap kompetitif. Chung-Herrera et al. (2003) melakukan penelitian mengenai kompetensi kepemimpinan dan menemukan delapan tipe faktor kompetensi kepemimpinan dalam industri perhotelan. Model kompetensi adalah sebuah alat deskriptif yang mengidentifikasi pengetahuan, ketrampilan, kemampuan dan perilaku yang dibutuhkan untuk bekerja efektif dalam sebuah organisasi. Model kompetensi fokus pada perilaku dibandingkan sifat personal, karena sifat personal biasanya sulit untuk diukur secara akurat.

Penelitian Chung-Herrera et al., (2003) menemukan delapan faktor kompetensi kepemimpinan yaitu:

1. Self-management, yang terdiri dari etika dan integritas, manajemen waktu, fleksibilitas dan adaptibility, dan pengembangan diri.

2. Strategic positioning, yang terdiri dari kesadaran akan kebutuhan pelanggan, komitmen untuk kualitas, mengelola manajemen stakeholder dan kepedulian masyarakat.

3. Implementation, yang mencakup perencanaan, mengarahkan orang lain, dan rekayasa-ulang.

4. Critical thinking, yang meliputi orientasi strategis, pengambilan keputusan, analisis, dan pengambilan risiko dan inovasi.

5. Communication, yang mencakup berbicara dengan dampak, memfasilitasi komunikasi terbuka, aktif mendengarkan dan komunikasi tertulis.

6. Interpersonal, yang terdiri dari dari membangun jaringan, mengelola konflik, dan menghargai keragaman.

7. Leadership, yang terdiri dari dari orientasi kerja sama tim, memupuk motivasi, ketabahan, mengembangkan orang lain, menghargai perubahan dan fleksibilitas kepemimpinan.

8. Industry knowledge, yaitu keahlian bisnis dan industri.

\section{Budaya Organisasi}

Robbins (2001:510) menjelaskan bahwa budaya organisasi merujuk kepada suatu sistem bersama yang dianut oleh anggota-anggota yang membedakan dengan organisasi lain. Sistem yang dianut bersama adalah seperangkat karakter kunci dari nilai-nilai organisasi. Budaya sebagai konsep, memiliki sejarah panjang. Dalam dekade terakhir telah digunakan oleh beberapa peneliti organisasi dan manajer untuk menunjukkan iklim dan praktek yang mengembangkan organisasi serta menangani orang atau merujuk kepada nilai-nilai dan kepercayaan organisasi.

Menurut Daft (2010, 336), budaya adalah seperangkat nilai, norma, panduan kepercayaan dan pemahaman yang dianut oleh anggota-anggota organisasi dan diajarkan kepada anggota baru sebagai cara untuk berpikir, merasakan, dan berperilaku. Budaya organisasi ada di dua tingkatan. Tingkatan pertama adalah bagian permukaan merupakan artifak yang terlihat dan perilaku yang tampak yaitu cara orang berpakaian, bertindak, jenis sistem pengendalian dan struktur kekuasaan yang digu- 
nakan oleh perusahaan, simbol-simbol, cerita, dan upacara anggota organisasi. Unsur-unsur yang terlihat di budaya namun mencerminkan nilai-nilai lebih dalam dalam pikiran anggota organisasi. Tingkatan kedua adalah nilai-nilai yang mendasari, asumsi, keyakinan, dan proses berpikir beroperasi secara tidak sadar untuk mendefinisikan budaya sejati.

\section{Karakteristik Budaya Organisasi}

Luthans (1995:497) menjelaskan bahwa budaya organisasi memiliki beberapa karakteristik penting. Beberapa dari yang paling mudah disepakati adalah sebagai berikut:

1. Pengamatan perilaku regular. Ketika anggota organisasi berinteraksi satu sama lain, mereka menggunakan bahasa umum, istilah, dan ritual yang berhubungan dengan penghormatan dan sikap.

2. Norma-norma. Standar perilaku yang ada, termasuk panduan pada berapa banyak pekerjaan yang harus dilakukan.

3. Nilai-nilai dominan. Ada nilai-nilai utama yang disepakati oleh anggota organisasi. Contoh khas adalah kualitas produk yang tinggi, ketidakhadiran (pembolosan) yang rendah, dan efisiensi yang tinggi.

4. Filosofi. Ada kebijakan yang menetapkan keyakinan organisasi tentang bagaimana karyawan dan pelanggan diperlakukan.

5. Peraturan. Ada panduan yang ketat terkait dengan kelangsungan hidup bersama di organisasi. Pendatang baru harus belajar peraturan mereka untuk diterima sebagai anggota penuh grup.

6. Iklim organisasi. Ini adalah keseluruhan perasaan yang disampaikan oleh fisik tata letak, cara peserta berinteraksi, dan cara anggota organisasi memperlakukan diri mereka dengan pelanggan atau pihak luar.

Collins dan Porras (2000:338) menyatakan bahwa budaya organisasi merujuk kepada satu sistem bersama makna yang dipegang oleh anggota yang membedakan satu organisasi dari organisasi lain. Mereka percaya bahwa makna ini bersama serangkaian karakteristikkarakteristik kunci, dan bahwa nilai-nilai organisasi dan esensi dari budaya organisasi dapat ditangkap di tujuh karakteristik utama. Karakteristik ini adalah:

1. Inovasi dan risiko. Sejauh mana karyawan yang didorong untuk menjadi inovatif dan mengambil risiko.

2. Perhatian terhadap detail. Sejauh mana karyawan diharapkan untuk menunjukkan ketepatan analisis dan perhatian terhadap detail.

3. Orientasi hasil. Sejauh mana manajemen fokus pada hasil dibandingkan pada teknik dan proses yang digunakan untuk mencapai hasil tersebut.

4. Orientasi orang. Sejauh mana keputusan manajemen mempertimbangkan hasil pada orang-orang (secara individu) dalam organisasi.

5. Orientasi kelompok. Sejauh mana aktivitas pekerjaan yang dilakukan secara kelompok daripada individu.

6. Agresivitas. Sejauh mana orang-orang yang agresif dan kompetitif daripada santai.

7. Stabilitas. Sejauh mana kegiatan organisasi menekankan untuk menyeimbangkan status quo berbeda dengan pertumbuhan. 


\section{Perilaku Responsif}

Kotler \& Keller (2009:390) juga menjelaskan mengenai langkah-langkah yang dapat diambil oleh perusahaan jasa untuk meningkatkan pengendalian kualitas adalah:

1. Investasi pada perekrutan dan prosedur pelatihan yang baik. Merekrut karyawan yang baik dan menyediakan mereka pelatihan yang sangat baik adalah penting terlepas dari apakah karyawan adalah profesional yang sangat terampil atau pekerja dengan keterampilan rendah. Karyawan yang terlatih dengan baik menunjukkan karakteristik sebagai berikut:

a) Competence yaitu karyawan memiliki keterampilan dan pengetahuan yang diperlukan

b) Courtesy yaitu karyawan yang ramah, hormat dan perhatian

c) Credibility yaitu karyawan yang dapat dipercaya

d) Reliability yaitu karyawan melakukan pelayanan secara konsisten dan akurat

e) Responsiveness yaitu karyawan merespon dengan cepat atas permintaan dan masalah pelanggan

f) Communication yaitu karyawan membuat usaha untuk memahami pelanggan dan berkomunikasi dengan jelas.

2. Menstandarisasi proses kinerja jasa ke seluruh organisasi. Cetak biru jasa secara bersamaan dapat memetakan proses jasa, kontak pelanggan, dan bukti pelayanan dari sudut pandang pelanggan.

3. Memonitor kepuasan pelanggan. Menggunakan saran dan sistem keluhan, sistem pelanggan, survei pelanggan, dan perbandingan belanja.
Pada literatur Parasuraman et al. (1988), istilah perilaku responsif pada literatur dipandang dari dua fungsi pespektif berbeda yaitu pemasaran jasa dan manajemen operasi. Dari sudut pandang pemasaran jasa, perilaku responsif berkaitan dengan kesediaan untuk membantu pelanggan dan kecepatan jasa yang diberikan, sedangkan dari sudut pandang manajemen operasi, perilaku responsif lebih terkait dengan kecepatan dan berbagai produk/jasa yang ditawarkan. Kombinasi dari dua perspektif menjelaskan perilaku responsif sebagai kemampuan perusahaan untuk menyediakan kecepatan jasa dan ragam jasa serta kesediaan untuk membantu pelanggan dalam penyampaian proses jasa. Dari definisi tersebut, perilaku responsif mewakili kemampuan kumulatif dalam hal kinerja beberapa langkah seperti kualitas, kecepatan (fleksibilitas) dan jasa (Asree et al., 2010).

Sharifi dan Zhang (1999) menjelaskan bahwa kemampuan yang diperlukan organisasi adalah merespon lebih baik dengan perubahan yang terjadi di dalam lingkungan usahanya, yang secara dasar dibagi menjadi empat kategori yaitu perilaku responsif, kompetensi, fleksibiltas dan kecepatan. Pada kenyataannya semua kategori saling berhubungan. Perilaku responsif adalah kemampuan perusahaan untuk mengumpulkan informasi dari lingkungan komersial, untuk mengidentifikasi perubahan dan merespon dengan cepat terhadap perubahan tersebut baik reaktif atau secara proaktif, dan bangkit dari perubahan.

Kotler dan Keller (2009:390) menjelaskan bahwa harapan pelanggan berasal dari banyak sumber seperti pengalaman masa lalu, dari mulut ke mulut, dan iklan. Secara umum, pelanggan membandingkan antara jasa yang 
diterima dan jasa yang diharapkan. Pada model kualitas jasa, terdapat lima penentu dari kualitas jasa:

1. Reliability merupakan kemampuan untuk melakukan pelayanan yang tepat dijanjikan dan akurat.

2. Responsiveness merupakan kesediaan untuk membantu pelanggan dan menyediakan pelayanan yang cepat.

3. Assurance merupakan pengetahuan, kesopanan karyawan dan kemampuan untuk menyampaikan kepercayaan dan keyakinan.

4. Empathy merupakan kepedulian, perhatian individu terhadap pelanggan.

5. Tangibles merupakan penampilan fisik fasilitas, peralatan, karyawan, dan bahan komunikasi.

Perusahaan harus mampu memastikan kebutuhan dan keinginan pelanggan yang terealisasi dalam service yang dihasilkan perusahaan. Kualitas pelayanan adalah pemahaman yang cukup dari perusahaan tentang pelanggan agar mampu menciptakan nilai unggul bagi pelanggan. Perusahaan yang berkualitas dapat disebut sebagai sebuah perusahaan dengan kemampuan untuk mengidentifikasi, menganalisis, memahami dan menjawab kebutuhankebutuhan pelanggan. Kualitas pelayanan juga membantu perusahaan mempelajari masalah teknis pasar dan menyediakan evaluasi segmen mengenai pentingnya pasar dan nilai pertumbuhan (Taylor, 2001).

\section{Kepuasan Pelanggan}

Secara umum kepuasan adalah perasaan seseorang terhadap kesenangan atau kekecewaan yang dihasilkan dari membandingkan kinerja (hasil) produk/jasa yang diterima terhadap harapan mereka. Apabila kinerja jauh di bawah harapan, maka pelanggan akan kecewa. Apabila kinerja cocok (sama) dengan harapan, maka pelanggan akan puas. Apabila kinerja jauh melebihi harapan, maka pelanggan akan sangat puas (Kotler \& Keller 2009:400).

Apabila kepuasan pelanggan dapat tercapai maka perusahaan akan mendapat banyak manfaat. Tingkat kepuasan pelanggan yang tinggi dapat meningkatkan loyalitas pelanggan dan mencegah perputaran pelanggan, mengurangi sensitivitas pelanggan terhadap harga, mengurangi biaya kegagalan pemasaran, meningkatkan efektivitas iklan, dan meningkatkan reputasi bisnis (Fornell, 1992).

Menurut Lupiyoadi (2001), terdapat lima faktor utama yang harus diperhatikan oleh perusahaan dalam menentukan tingkat kepuasan pelanggan yaitu:

1. Kualitas produk. Pelanggan akan merasa puas bila hasil evaluasi mereka menunjukkan bahwa produk yang mereka konsumsi berkualitas. Konsumen rasional selalu menuntut produk yang berkualitas untuk setiap pengorbanan yang dilakukan untuk memperoleh produk tersebut. Kualitas yang baik akan memberikan nilai tambah di benak konsumen.

2. Kualitas pelayanan. Kualitas pelayanan terutama di bidang jasa, pelanggan akan merasa puas bila mereka mendapatkan pelayanan yang baik atau yang sesuai dengan yang diharapkan. Pelanggan yang puas akan menunjukkan kemungkinan untuk kembali membeli produk yang sama. Pelanggan yang puas cenderung akan memberikan persepsi terhadap produk perusahaan. 
3. Emosional. Pelanggan akan merasa bangga dan mendapatkan keyakinan bahwa orang lain akan kagum terhadap dia apabila menggunakan produk dengan merk tertentu yang cenderung mempunyai tingkat kepuasan yang lebih tinggi. Kepuasan yang diperoleh bukan karena kualitas dari produk tetapi nilai sosial atau self esteem yang membuat pelanggan menjadi puas terhadap merk tertentu.

4. Harga. Produk yang mempunyai kualitas yang sama tetapi menetapkan harga yang relatif murah akan memberikan nilai yang lebih tinggi kepada pelanggannya.

5. Biaya. Pelanggan tidak perlu mengeluarkan biaya tambahan atau tidak perlu membuang waktu untuk mendapatkan suatu produk atau jasa cenderung puas terhadap produk atau jasa itu.

Mengukur kepuasan pelanggan sangat bermanfaat bagi perusahaan dalam rangka mengevaluasi posisi perusahaan saat itu dibandingkan dengan pesaing dan pengguna akhir, serta menemukan bagian mana yang membutuhkan peningkatan. Menurut Kotler (2004), untuk mengetahui tingkat kepuasan pelanggan ada empat metode pengukuran yang perlu diperhatikan oleh perusahaan yaitu:

1. Sistem keluhan dan saran pelanggan. Setiap perusahaan yang berorientasi terhadap pelanggan memberikan kesempatan yang seluas-luasnya kepada pelanggan untuk menyampaikan saran, pendapat dan keluhan. Adapun metode yang digunakan bisa berupa kotak saran ataupun dengan menyediakan saluran telepon khusus.

2. Survei kepuasan pelanggan. Umumnya banyak penelitian mengenai kepuasan pelang- gan dilakukan dengan metode survei, baik melalui pos, telepon maupun wawancara langsung. Untuk mengukur kepuasan pelanggan dapat dilakukan dengan cara:

a. Pengukuran dapat dilakukan secara langsung dengan pertanyaan seperti ungkapan seberapa puas saudara terhadap pelayanan.

b. Responden diminta untuk menuliskan masalah-masalah yang mereka hadapi berkaitan dengan penawaran dari perusahaan dan juga dimintai untuk menuliskan perbaikan-perbaikan yang mereka sarankan.

c. Responden diberi pertanyaan mengenai seberapa besar mengharapkan atribut tertentu dan seberapa besar mereka rasakan.

d. Responden dapat merangking berbagai elemen dan penawaran berdasarkan derajat penting setiap elemen seberapa baik kinerja perusahaan dalam masingmasing elemen.

3. Ghost shopping. Metode ini dilaksanakan dengan cara mempekerjakan beberapa orang (ghost shopping) berperan sebagai pembeli yang memanfaatkan produk atau jasa perusahaan dan pesaing, sehingga dapat memprediksi tingkat kepuasan pelanggan atas produk tersebut.

4. Lost customer analysis. Dalam metode ini perusahaan menghubungi para pelanggan yang telah beralih ke perusahaan lain. Hal ini ditujukan untuk memperoleh informasi penyebab terjadinya peralihan pelanggan kepada perusahaan lain, sehingga dapat dijadikan sebagai bahan evaluasi selanjutnya. 


\section{Perumusan Hipotesis}

H1: Bahwa kompetensi kepemimpinan mempunyai pengaruh signifikan terhadap kepuasan pelanggan di PT Garuda Indonesia Kantor Cabang Surabaya.

H2: Bahwa kompetensi kepemimpinan mempunyai pengaruh signifikan terhadap kepuasan pelanggan melalui perilaku responsif karyawan frontliner di PT Garuda Indonesia Kantor Cabang Surabaya.

H3: Bahwa budaya organisasi mempunyai pengaruh signifikan terhadap kepuasan pelanggan PT Garuda Indonesia Kantor Cabang Surabaya.

H4: Bahwa budaya organisasi mempunyai pengaruh signifikan terhadap kepuasan pelanggan melalui perilaku responsif karyawan frontliner di PT Garuda Indonesia Kantor Cabang Surabaya.

\section{METODOLOGI PENELITIAN}

\section{Populasi dan Sampel Penelitian}

Pengumpulan data pada penelitian ini dilakukan dengan menyebarkan kuesioner pada responden di perusahaan jasa antara karyawan frontliner dengan pelanggan yang memliki interaksi tinggi serta menyusun kuesioner untuk pelanggan yang berbeda secara redaksional namun tetap mengacu pada esensi yang sama. Teknik pengumpulan data untuk masingmasing jenis responden ini berbeda. Teknik pengumpulan data yang digunakan untuk karyawan frontliner adalah purposive sampling, yaitu dengan memilih karyawan dengan minimal telah waktu kerja satu tahun untuk karyawan. Kriteria sampel untuk pelanggan PT Garuda Indonesia adalah pelanggan yang datang ke kantor PT GAI cabang Surabaya dan penye- baran kuesioner pada pelanggan dilakukan pada hari yang sama dengan penyebaran pada karyawan frontliner. Penyebaran kuesioner ini dilakukan sendiri oleh peneliti dengan persetujuan pimpinan kantor PT GAI.

\section{Definisi Operasional dan Pengukuran Variabel}

\section{Variabel Independen}

1. Kompetensi Kepemimpinan

Dalam variabel kompetensi kepemimpinan terdapat beberapa dimensi antara lain:

a. Self-management, yang terdiri dari integritas, etika, manajemen waktu, adaptibility, dan pengembangan diri.

b. Strategic positioning, yang terdiri dari kesadaran akan kebutuhan pelanggan, komitmen untuk kualitas, mengelola manajemen stakeholder dan kepedulian masyarakat.

c. Communication, yang terdiri dari percakapan dua arah, memfasilitasi komunikasi terbuka, aktif mendengarkan dan komunikasi tertulis.

d. Interpersonal, yang terdiri dari dari membangun jaringan, mengelola konflik, dan menghargai keragaman.

e. Leadership, yang terdiri dari dari orientasi kerja sama tim, memupuk motivasi, mengembangkan orang lain dan menghargai perubahan.

2. Budaya Organisasi

Dalam variabel budaya organisasi terdapat beberapa indikator antara lain:

a. Perhatian terhadap detail. Sejauh mana karyawan diharapkan untuk menunjukkan ketepatan analisis dan perhatian terhadap detail. 
b. Orientasi hasil. Sejauh mana manajemen fokus pada hasil dibandingkan pada teknik dan proses yang digunakan untuk mencapai hasil tersebut.

c. Orientasi orang. Sejauh mana keputusan manajemen mempertimbangkan hasil dari orang-orang (secara individu) dalam organisasi.

d. Orientasi kelompok. Sejauh mana aktivitas pekerjaan yang dilakukan secara kelompok daripada individu.

\section{Variabel Intervening}

\section{Perilaku responsif karyawan}

Dalam variabel ini terdapat beberapa indikator antara lain:

1. Reliability merupakan kemampuan untuk melakukan pelayanan yang tepat dijanjikan dan akurat.

2. Responsiveness merupakan kesediaan untuk membantu pelanggan dan menyediakan pelayanan yang cepat.

3. Assurance merupakan pengetahuan, kesopanan karyawan dan kemampuan untuk menyampaikan kepercayaan dan keyakinan.

4. Empathy merupakan ketentuan untuk peduli, perhatian individu terhadap pelanggan.

5. Tangibles merupakan penampilan fisik fasilitas, peralatan, karyawan, dan bahan komunikasi.

\section{Variabel Dependen}

\section{Kepuasan pelanggan}

Dalam variabel ini terdapat beberapa indikator antara lain:
1. Reliability merupakan kemampuan untuk melakukan pelayanan yang tepat dijanjikan dan akurat.

2. Responsiveness merupakan kesediaan untuk membantu pelanggan dan menyediakan pelayanan yang cepat.

3. Assurance merupakan pengetahuan, kesopanan karyawan dan kemampuan untuk menyampaikan kepercayaan dan keyakinan.

4. Empathy merupakan kepedulian, perhatian individu terhadap pelanggan.

5. Tangibles merupakan penampilan fisik fasilitas, peralatan, karyawan, dan bahan komunikasi.

\section{HASIL PENELITIAN DAN PEMBAHASAN}

\section{Uji Asumsi Klasik}

\section{a. Uji Multikolinieritas}

\section{Uji Multikolinieritas Pada Hubungan X1, X2 terhadap $\mathrm{Z}$}

Hasil perhitungan nilai Variance Inflation Factor (VIF) juga menunjukkan hal yang sama yaitu bahwa variabel bebas kompetensi kepemimpinan (X1) dan budaya organisasi (X2), mempunyai nilai VIF $<10$ sehingga mengindikasikan bahwa tidak terjadi multikolinieritas antar variabel bebas dalam model regresi, adapun nilai VIF variabel X1 dan X2 sebesar 1,051 .

Uji Multikolinieritas Pada Hubungan X1, X2, dan $\mathrm{Z}$ terhadap $\mathrm{Y}$

Hasil perhitungan nilai Variance Inflation Factor (VIF) juga menunjukkan hal yang sama yaitu bahwa variabel bebas kompetensi kepemimpinan (X1) dan budaya organisasi (X2), 
dan perilaku responsif karyawan (Z) mempunyai nilai VIF < 10 sehingga mengindikasikan bahwa tidak terjadi multikolinieritas antar variabel bebas dalam model regresi, adapun nilai VIF variabel $\mathrm{X} 1=1,210, \mathrm{X} 2=1,321$, dan $Z=1,338$.

\section{b. Uji Heterokedastisitas}

\section{Uji Heterokedastisitas Pada Hubungan X1,} X2 terhadap Z

Uji heteroskedastisitas dilakukan dengan melihat pola grafik scatterplot. Pada Scatterplot model regresi antara variabel kompetensi kepemimpinan (X1) dan budaya organisasi (X2) terhadap perilaku responsif karyawan (Z) terlihat bahwa titik-titik menyebar di atas dan di bawah angka 0 pada sumbu Y, maka dapat dikatakan tidak terjadi heterokedastisitas artinya bahwa ada kesamaan varian antara data pengamatan yang satu dengan data pengamatan yang lain.

Uji Heterokedastisitas Pada Hubungan X1, X2,dan Z terhadap Y

Pada Scatterplot model regresi antara variabel kompetensi kepemimpinan (X1), budaya organisasi (X2) dan perilaku responsif karyawan $(Z)$ terhadap kepuasan pelanggan (Y) terlihat bahwa titik-titik menyebar di atas dan di bawah angka 0 pada sumbu Y, maka dapat dikatakan tidak terjadi heterokedastisitas artinya bahwa ada kesamaan varian antara data pengamatan yang satu dengan data pengamatan yang lain.

\section{c. Uji Normalitas}

Uji Normalitas Pada Hubungan X1, X2 terhadap $\mathbf{Z}$

Dengan melihat normal probability plot di atas tampak bahwa gambaran data yang sesungguhnya mempunyai kecenderungan mengikuti garis normal, sehingga dapat dikatakan bahwa data yang ada cenderung berdistribusi normal.

Uji Normalitas Pada Hubungan X1, X2, Z terhadap Y

Dengan melihat normal probability plot di atas tampak bahwa gambaran data yang sesungguhnya mempunyai kecenderungan mengikuti garis normal, sehingga dapat dikatakan bahwa data yang ada cenderung berdistribusi normal.

\section{Uji Regresi Linier Berganda}

\section{a. Analisis Koefisien Determinasi}

Model Summary ${ }^{\mathrm{b}}$

\begin{tabular}{|c|c|c|c|c|}
\hline Model & $\mathbf{R}$ & R Square & $\begin{array}{c}\text { Adjusted R } \\
\text { Square }\end{array}$ & $\begin{array}{c}\text { Std. Error of } \\
\text { the Estimate }\end{array}$ \\
\hline 1 & $.503^{\mathrm{a}}$ & .253 & .215 & .669 \\
\hline
\end{tabular}

a. Predictors: (Constant), X2, X1

b. Dependent Variable: $\mathrm{Z}$

Sumber: hasil olahan

Melihat hasil output SPSS tersebut di atas diketahui Adjusted $\mathrm{R}$ square sebesar 0,253. Hal ini berarti 25,3\% variasi perilaku responsif karyawan, besarnya dapat dijelaskan oleh variasi dari kedua variabel bebas kompetensi kepemimpinan (X1) dan budaya organisasi (X2). Sedangkan sisanya 74,7\% dijelaskan 
oleh sebab-sebab yang lain di luar model, yang tidak diteliti disini.

b. Analisis Uji Kelayakan Model (Uji Simultan Pada Hubungan X1, X2 terhadap Z)

\begin{tabular}{|c|c|c|c|c|c|c|}
\hline & Model & $\begin{array}{l}\text { Sum of } \\
\text { Squares }\end{array}$ & df & $\begin{array}{l}\text { Mean } \\
\text { Square }\end{array}$ & F & Sig. \\
\hline \multirow{3}{*}{1} & Regression & 5.914 & 2 & 2.957 & 6.600 & $.003^{\mathrm{b}}$ \\
\hline & Residual & 17.473 & 39 & .448 & & \\
\hline & Total & 23.387 & 41 & & & \\
\hline
\end{tabular}

a. Dependent Variable: Z

b. Predictors: (Constant), X2, X1

Sumber: hasil olahan

Dari uji Anova atau $\mathrm{F}_{\text {test }}$, didapat $\mathrm{F}_{\text {hitung }}$ sebesar 6.600 dengan tingkat probabilitas 0,003 (signifikansi). $\mathrm{F}_{\text {tabel }}$ dengan $\mathrm{df}$ (degree of freedom) $1=2$ dan df $2=39$ dan derajat kepercayaan 5\% adalah 3,23. Karena probabilitas $(0,003)$ lebih kecil dari 0,05 atau 5\% dan $\mathrm{F}_{\text {hitung }}>\mathrm{F}_{\text {tabel }}$ maka model regresi dapat digunakan untuk memprediksi perilaku responsif karyawan $(Z)$ atau dapat dikatakan bahwa kompetensi kepemimpinan (X1) dan budaya organisasi (X2) secara bersama-sama berpengaruh terhadap perilaku responsif karyawan (Z).

\section{c. Analisis Koefisien Determinasi}

Model Summary ${ }^{\mathrm{b}}$

\begin{tabular}{|c|c|c|c|c|}
\hline Model & R & R Square & $\begin{array}{c}\text { Adjusted } \\
\text { R Square }\end{array}$ & $\begin{array}{c}\text { Std. Error of } \\
\text { the Estimate }\end{array}$ \\
\hline 1 & $.723^{\mathrm{a}}$ & .523 & .486 & .593 \\
\hline
\end{tabular}

a. Predictors: (Constant), Z, X1, X2

b. Dependent Variable: Y

Sumber: hasil olahan
Melihat hasil output SPSS tersebut di atas diketahui Adjusted $\mathrm{R}$ square sebesar 0,523 . Hal ini berarti 52,3\% variasi perilaku responsif karyawan, besarnya dapat dijelaskan oleh variasi dari variabel bebas kompetensi kepemimpinan (X1), budaya organisasi (X2), perilaku responsif karyawan (Z). Sedangkan sisanya $47,7 \%$ dijelaskan oleh sebab-sebab yang lain di luar model yang tidak diteliti disini.

\section{d. Analisis Uji Kelayakan Model (Uji Simultan Pada Hubungan X1, X2, Z terhadap Y)}

\begin{tabular}{|c|c|c|c|c|c|c|}
\hline \multicolumn{7}{|c|}{ ANOVA $^{a}$} \\
\hline \multicolumn{2}{|c|}{ Model } & Sum of & $\mathrm{df}$ & Mean & F & Sig. \\
\hline \multirow{3}{*}{1} & Regression & 14.648 & 3 & 4.883 & 13.900 & $.000^{\mathrm{b}}$ \\
\hline & Residual & 13.349 & 38 & .351 & & \\
\hline & Total & 27.997 & 41 & & & \\
\hline
\end{tabular}

a. Dependent Variable: Y

b. Predictors: (Constant), Z, X1, X2

Sumber: hasil olahan

Dari uji Anova atau $\mathrm{F}_{\text {test }}$, didapat $\mathrm{F}_{\text {hitung }}$ sebesar 13.900 dengan tingkat probabilitas 0,000 (signifikansi). $\mathrm{F}_{\text {tabel }}$ dengan $\mathrm{df}$ (degree of freedom) $1=3$ dan $\mathrm{df} 2=38$ dan derajat kepercayaan 5\% adalah 2,84. Karena probabilitas $(0,000)$ lebih kecil dari 0,05 atau $5 \%$ dan $\mathrm{F}_{\text {hitung }}>\mathrm{F}_{\text {tabel }}$ maka model regresi dapat digunakan untuk memprediksi kepuasan pelanggan (Y) atau dapat dikatakan bahwa kepemimpinan (X1), budaya organisasi (X2), dan perilaku responsif karyawan (Z) secara bersama-sama berpengaruh terhadap kepuasan pelanggan $(\mathrm{Y})$. 
e. Analisis Pengujian Hipotesis Uji Parsial (Hubungan X1, X2 terhadap Z)

Coefficients $^{\mathrm{a}}$

\begin{tabular}{|c|c|c|c|c|c|c|c|}
\hline \multirow{2}{*}{ Model } & \multicolumn{2}{|c|}{$\begin{array}{l}\text { Unstandardized } \\
\text { Coefficients }\end{array}$} & \multirow{2}{*}{$\frac{\begin{array}{c}\text { Standardized } \\
\text { Coefficients }\end{array}}{\text { Beta }}$} & \multirow{2}{*}{$\mathrm{T}$} & \multirow{2}{*}{ Sig. } & \multicolumn{2}{|c|}{$\begin{array}{c}\text { Collinearity } \\
\text { Statistics }\end{array}$} \\
\hline & B & Std. Error & & & & Tolerance & VIF \\
\hline (Constant) & -.444 & 1.200 & & -.370 & .713 & & \\
\hline $1 \mathrm{X} 1$ & .461 & .189 & .345 & 2.434 & .020 & .952 & 1.051 \\
\hline $\mathrm{X} 2$ & .646 & .204 & .449 & 3.167 & .003 & .952 & 1.051 \\
\hline
\end{tabular}

a. Dependent Variable: Z

Sumber: hasil olahan

Dari tabel di atas, dapat dilihat pengaruh dari masing-masing variabel kompetensi kepemimpinan dan budaya organisasi terhadap perilaku responsif karyawan dapat dilihat dari arah tanda dan tingkat signifikansi (probabilitas). Hasil pengujian hipotesis masing-masing variabel kompetensi kepemimpinan dan budaya organisasi secara parsial terhadap perilaku responsif karyawan dapat dianalisis sebagai berikut:

- Uji hipotesis pengaruh kompetensi kepemimpinan terhadap perilaku responsif karyawan

Variabel kompetensi kepemimpinan (X1) mempunyai pengaruh yang signifikan atau dengan kata lain $\mathrm{H}_{0}$ ditolak, hal ini bisa dilihat dari nilai t hitung untuk variabel kompetensi kepemimpinan (X1) mempunyai nilai [ $\mathrm{t}$ hitung $=2.434]>(\mathrm{t}$ tabel $=$ 2,021) sedangkan nilai probabilitas signifikansi untuk X1 sebesar 0,020, nilai terse- but kurang dari 0,05 ( $\alpha=5 \%)$. Karena nilai t hitung $>\mathrm{t}$ tabel $\left(\mathrm{t}_{\mathrm{n}-2, \alpha / 2)}\right.$ dan angka signifikansi $<0,05$ maka tolak Ho, artinya bahwa variabel kompetensi kepemimpinan (X1) secara individual mempengaruhi variabel perilaku responsif karyawan (Z).

- Uji hipotesis pengaruh budaya organisasi terhadap perilaku responsif karyawan Variabel budaya organisasi (X2) mempunyai pengaruh yang signifikan atau dengan kata lain $\mathrm{H}_{0}$ ditolak, hal ini bisa dilihat dari nilai t hitung untuk variabel budaya organisasi mempunyai nilai ( $\mathrm{t}$ hitung $=3.167)>(\mathrm{t}$ tabel $=2,021)$ sedangkan nilai probabilitas signifikansi untuk X2 sebesar 0,003 , nilai tersebut kurang dari $0,05(\alpha=5 \%)$. Karena nilai $t$ hitung $>\mathrm{t}$ tabel $\left(\mathrm{t}_{\mathrm{n}-2, \alpha / 2)}\right.$ dan angka signifikansi $<0,05$ maka tolak Ho, artinya bahwa variabel budaya organisasi (X2) secara individual mempengaruhi variabel perilaku responsif karyawan (Z). 


\section{f. Analisis Pengujian Hipotesis Uji Parsial (Hubungan X1, X2, Z terhadap Y)}

Coefficients $^{\mathrm{a}}$

\begin{tabular}{|l|r|r|r|r|r|r|r|}
\hline \multirow{2}{*}{ Model } & \multicolumn{2}{|c|}{$\begin{array}{c}\text { Unstandardized } \\
\text { Coefficients }\end{array}$} & $\begin{array}{c}\text { Standardized } \\
\text { Coefficients }\end{array}$ & \multirow{2}{*}{$\mathrm{T}$} & \multirow{2}{*}{ Sig. } & \multicolumn{2}{|c|}{$\begin{array}{c}\text { Collinearity } \\
\text { Statistics }\end{array}$} \\
\cline { 2 - 4 } \cline { 7 - 8 } & \multicolumn{1}{c|}{$\mathrm{B}$} & Std. Error & \multicolumn{1}{c|}{ Beta } & & & Tolerance & VIF \\
\hline (Constant) & -2.119 & 1.065 & & -1.990 & .054 & & \\
$\mathrm{X} 1$ & .545 & .180 & .373 & 3.028 & .004 & .826 & 1.210 \\
$\mathrm{X} 2$ & .731 & .202 & .465 & 3.609 & .001 & .757 & 1.321 \\
$\mathrm{Z}$ & .323 & .142 & .296 & 2.281 & .028 & .747 & 1.338 \\
\hline
\end{tabular}

a. Dependent Variable: Y

Sumber: hasil olahan

Dari tabel di atas, dapat dilihat pengaruh dari masing-masing variabel kompetensi kepemimpinan, budaya organisasi dan perilaku responsif karyawan terhadap kepuasan pelanggan dapat dilihat dari arah tanda dan tingkat signifikansi (probabilitas). Hasil pengujian hipotesis masing-masing variabel kompetensi kepemimpinan dan budaya organisasi secara parsial terhadap perilaku responsif karyawan dapat dianalisis sebagai berikut:

- Uji hipotesis pengaruh kompetensi kepemimpinan terhadap kepuasan pelanggan Variabel kompetensi kepemimpinan (X1) mempunyai pengaruh yang signifikan atau dengan kata lain $\mathrm{H}_{0}$ ditolak, hal ini bisa dilihat dari nilai t hitung untuk variabel kompetensi kepemimpinan (X1) mempunyai nilai ( $\mathrm{t}$ hitung $=3,028)>(\mathrm{t}$ tabel $=$ 2,021) sedangkan nilai probabilitas signifikansi untuk X1 sebesar 0,004, nilai tersebut kurang dari 0,05 $(\alpha=5 \%)$. Karena nilai $\mathrm{t}$ hitung $>\mathrm{t}$ tabel $\left(\mathrm{t}_{\mathrm{n}-2, \alpha / 2)}\right.$ dan angka signifikansi $<0,05$ maka tolak Ho, artinya bahwa variabel kompetensi kepemimpinan (X1) secara individual mempengaruhi variabel kepuasan pelanggan $(\mathrm{Y})$.
- Uji hipotesis pengaruh budaya organisasi terhadap kepuasan pelanggan

Variabel budaya organisasi (X2) mempunyai pengaruh yang signifikan atau dengan kata lain $\mathrm{H}_{0}$ ditolak, hal ini bisa dilihat dari nilai t hitung untuk variabel budaya organisasi mempunyai nilai ( $\mathrm{t}$ hitung $=3,609)>(\mathrm{t}$ tabel $=2,021$ ) sedangkan nilai probabilitas signifikansi untuk X2 sebesar 0,001, nilai tersebut kurang dari $0,05(\alpha=5 \%)$. Karena nilai t hitung $>$ tabel $\left(\mathrm{t}_{\mathrm{n}-2, \alpha / 2)}\right.$ dan angka signifikansi $<0,05$ maka tolak Ho, artinya bahwa variabel budaya organisasi (X2) secara individual mempengaruhi variabel kepuasan pelanggan $(\mathrm{Y})$.

- Uji hipotesis pengaruh perilaku responsif karyawan terhadap kepuasan pelanggan Variabel perilaku responsif karyawan (Z) mempunyai pengaruh yang signifikan atau dengan kata lain $\mathrm{H}_{0}$ ditolak, hal ini bisa dilihat dari nilai $\mathrm{t}$ hitung untuk variabel perilaku responsif karyawan $(Z)$ mempunyai nilai $(\mathrm{t}$ hitung $=2,281)>(\mathrm{t}$ tabel $=$ 2,021) sedangkan nilai probabilitas signifikansi untuk Z sebesar 0,028 , nilai tersebut kurang dari 0,05 ( $\alpha=5 \%)$. Karena nilai t 
hitung $>\mathrm{t}$ tabel $\left(\mathrm{t}_{\mathrm{n}-2, \alpha / 2)}\right.$ dan angka signifikansi $<0,05$ maka tolak Ho, artinya bahwa variabel perilaku responsif karyawan (Z) secara individual mempengaruhi variabel kepuasan pelanggan (Y).

Hasil analisis di atas jika digambarkan, maka bentuk hubungan variabel kompetensi kepemimpinan, budaya organisasi, perilaku responsif karyawan dan kepuasan pelanggan adalah sebagai berikut:

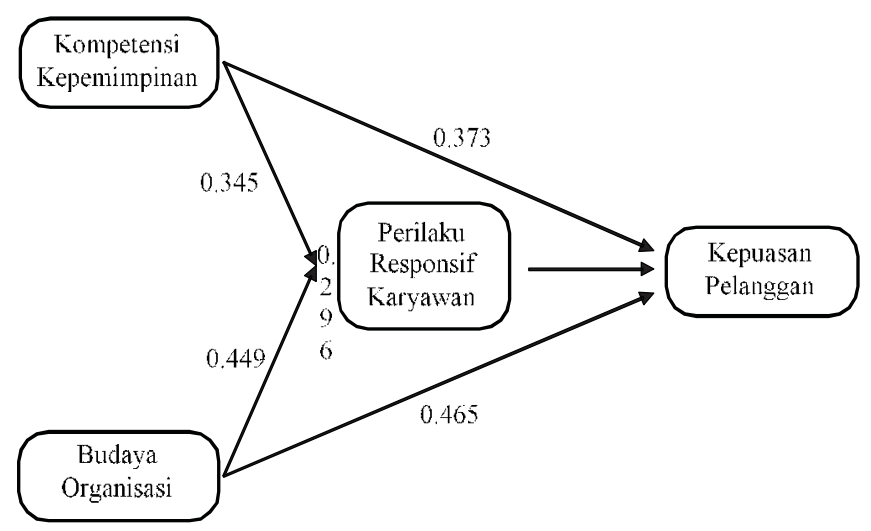

Suatu variabel dikatakan sebagai variabel intervening/mediasi jika hubungan tidak langsung lebih besar dari hubungan langsung. Besarnya hubungan tidak langsung X1 terhadap $\mathrm{Y}=0,345 \times 0,296=0,102$. Besarnya hubungan langsung X1 terhadap $\mathrm{Y}=0,373$ lebih besar dari 0,102 artinya variabel perilaku responsif karyawan belum mampu memediasi variabel kompetensi kepemimpinan terhadap variabel kepuasan pelanggan akan tetapi variabel kompetensi kepemimpinan berhubungan langsung dengan variabel kepuasan pelanggan. Besarnya hubungan tidak langsung X2 terhadap $Y=0,449 \times 0,296=0,133$. Besarnya hubungan langsung $\mathrm{X} 2$ terhadap $\mathrm{Y}=$ 0,465 lebih besar dari 0,133 artinya variabel perilaku responsif karyawan belum mampu memediasi dari variabel budaya organisasi ter- hadap variabel kepuasan pelanggan akan tetapi variabel budaya organisasi berhubungan langsung dengan variabel kepuasan pelanggan.

Pada penelitian ini, budaya organisasi di PT. Garuda Indonesia cabang Surabaya merupakan variabel dominan yang dapat mempengaruhi besarnya kepuasan pelanggan dibanding kompetensi kepemimpinan tanpa dimediasi oleh perilaku responsif karyawan. Hal ini menunjukkan bahwa semakin tingginya kompetensi kepemimpinan dan semakin kuatnya budaya organisasi di PT. Garuda Indonesia kantor cabang Surabaya akan semakin meningkatkan kepuasan pelanggannya.

\section{IMPLIKASI DAN KETERBATASAN}

\section{Implikasi}

Bagi manajemen PT Garuda Indonesia Kantor Cabang Surabaya, hasil penelitian ini dapat memberikan beberapa masukan:

a. Pemimpin sudah mampu membangun kepuasan pelanggan. Hal tersebut menunjukkan bahwa pelanggan sudah percaya pada proses rekrutmen yang dapat menghasilkan pemimpin yang berkompetensi. Dengan demikian pemimpin harus dapat mempertahankan kepercayaan yang diberikan pada pelanggan. Pemimpin juga melakukan pengarahan pada karyawan khususnya karyawan frontliner dalam hal pemecahan masalah agar pelanggan merasa puas.

b. Diharapkan supervisor mampu memberikan dukungan yang dapat menciptakan kondisi kerja yang dinamis serta mengarahkan para karyawan frontliner untuk bisa mengatasi apabila terdapat permasalahan serta dapat memecahkan masalah tersebut dengan baik. 
c. Ukuran-ukuran kepuasan pelanggan seyogyanya dapat dipahami dengan jelas oleh semua karyawan terutama karyawan frontliner dan melibatkan semua karyawan, terutama mengenai keterkaitan ukuran-ukuran perilaku responsif dengan visi kepuasan pelanggan.

d. Organisasi memberikan kemudahan bagi karyawan dalam melakukan komunikasi dengan pimpinan dengan memberikan fasilitas yang dapat digunakan karyawan untuk menyebarkan dan mendapatkan informasi.

\section{Keterbatasan}

Beberapa keterbatasan dalam penelitian ini antara lain.

1. Penelitian ini dilakukan pada satu perusahaan saja, sehingga tingkat generalisasi penelitian ini sangat rendah.

2. Pengamatan dalam penelitian ini hanya dilakukan di tahun 2013.

3. Penggunaan kuesioner dapat menyebabkan respons bias dari responden akibat ketidakjujuran maupun responden tidak serius dalam menjawab pertanyaan-pertanyaan.

\section{DAFTAR REFERENSI}

Agung, Lilik A.M. 2007. Human Capital Competensies, Sketsa-Sketsa Praktik Human Capital Berbasis Kompetensi. Jakarta: Penerbit PT Elex Media Komputindo.

Asree, Susita, M. Zain, and M.R. Razalli. 2010. Influence of leadership competency and organizational culture on responsiveness and performance of firms. International Journal Contemporary
Hospitality Management. Vol. 22 No. 4 pp. 500-516.

Buyukozkan, Gulcin. 2004. An organizational information network for corporate responsiveness and enhanced performance. Journal of Manufacturing Technology Management. Volume 15. Number 1. Pp 57-67.

Chung-Herrera, B.G., Enz, C.A. and Lankau, M.J. 2003. Grooming future hospitality leaders: a competencies model. Cornell Hotel and Restaurant Administration Quarterly, June, pp. 17-25.

Darwis, K. Tommy \& Surna Tjahja Djajadiningrat. 2010. The relationship of leadership styles and organizational culture. Jurnal Manajemen Teknologi. Vol.9. No.3. pp. 323-37.

Emiliani, M. L. 2008. Linking leaders' belifs to their behaviors and competencies. Management Decision. Vol. 41. No. 9. Pp. 893-910.

Fornell, C. 1992. A National Customer Satisfaction Barometer: The Swedish Experience. Journal of Marketing. Vol. 60. pp. 7-17

Hutapea, P. dan N.Toha. 2008. Kompetensi Plus Teori, Desain, dan Penerapan untuk HR dan Organisasi yang Dinamis. Jakarta: PT. Gramedia Pustaka Utama

Irawan, Handi D. 2002. 10 Prinsip Kepuasan Pelanggan. Jakarta: Elex Media Komputindo.

Kotler, Philip \& Kevin Lane Keller. 2009. Marketing Management. Thirteenth Edition. New Jersey: Prentice Hall International, Inc.

Lupiyoadi, Rambat. 2001. Manajemen Pemasaran Jasa Teori dan Praktik. Edisi Pertama. Jakarta: Penerbit Salemba Empat. 
Luthans, Fred. 1995. Organizational Behavior. Seventh Edition. Singapore: McGraw-Hill.

Moulton, Steven, Oki Sunardi, \& Gino Ambrosini. 2006. Competency: development, integraton, and application. Business \& Management Journal Bunda Mulia. Vol: 2, No.1. pp. 12-20.

Newstrom, W. John. 2011. Organizational Behavior. Thirteen Edition. Singapore: McGraw-Hill.

Parasuraman, A., Zeithamal, Valarie.A. and Berry, Leonardo.C. (1988). SERVQUAL: A Multiple-Item Scale for Measuring Consumer Perceptions of Service Quality. Journal of Retailing. Vol. 64 No.1, pp. 12-40.

Pizam, Abraham \& Taylor Ellis. 1999. Customer satifaction and its measurement in hospitality enterprises. International Journal of Contemporary Hospitality
Management. Vol.11. No.7. pp. 326339.

Robbins, P. Stephen. 2001. Organizational Behavior. Nineth Edition. New Jersey: Prentice Hall International, Inc.

Sharifi, H. \& Zhang Z. 1999. A methodology for achieving agility in manufacturing organizations: an introduction. International Journal of Production Economics. Vol. 62. pp: 7-22.

Taylor, Steven A. 2001. Assessing the use of regression analysis in examining service recovery in the insurance industry: relating service quality, customer satisfaction, and customer trust. Journal of Insurance Issues. Vol. 24, pp. 30-57.

Wibowo, 2008. Manajemen Kinerja. Edisi Dua. Jakarta: PT RajaGrafindo Persada Yukl, Yukl, Gary. 2006. Leadership In Organizations. Sixth Edition. New York: Pearson Prentice Hall. 